\title{
The Black-tailed Godwit. By F. Haverschmidt. E. J. Brill, Leiden,
} 18 guilders.

This excellent little summary of the distribution, breeding and migration of the black-tailed godwit, mainly in the Netherlands, is by a well known Dutch ornithologist who now lives in Surinam, $\mathrm{He}$ mentions briefly the return of this fine wader as a breeding species to Britain and also its arrival as a winter visitor on our southern and western shores, but does not mention that these latter birds are believed to be largely derived from the increasing Icelandic population. It is good to see a short section specifically devoted to protection and the future of the godwit, for all too many scientists still believe this aspect to be beneath their notice. So long as the Dutch continue to produce milk, butter and cheese, so long will there be rich grazing meadows for the godwits to nest in, but there is a danger that as these meadows are "improved," they will become less attractive to birds.

Many British people may be slightly shocked to learn that searching for lapwings' eggs is a kind of national sport in Holland, especially in Friesland, although a close season is strictly imposed on 12th April (19th April in Friesland). There is even a federation of local bird societies devoted to this sport and to seeing that the close season is obeyed. Personally I would rather see people take an interest in wild life in this rather old-fashioned way, than see them wander the countryside listening to a transistor radio.

\section{R. S. R. FITTER}

\section{African Game Ranching. By F. Dasmann. Pergamon Press, 7s. 68.}

The last decade has seen the emergence of a new concept of conservation, the dynamic approach through management as opposed to preservation and non-intervention. In this slim volume the author presents an account of a research project in Rhodesia, and relates it to the overall pattern of wildlife conservation and related problems in Africa. He makes a strong case for a form of land use for marginal lands through management and cropping of wild life. His approach is based on the concept that the many species of indigenous wild herbivores are much better adapted to African conditions than are the few species and breeds of introduced domestic animals. There is good evidence from many parts of Africa that great numbers of wild animals can be supported by marginal lands, without damage to the habitat, whereas lands cleared of game and given over to cattle almost invariably deteriorate. He also argues the parallel case for domestication of indigenous grazing animals.

The second half of the book is devoted to a very readable and clear presentation of these ideas and to their practical application. An inventory of mammals present in a study area was compiled and cropping plans drawn up showing the numbers of each species that could be cropped and still be replaced by young animals. The balance sheet showed a much higher yield of meat per acre from game than from cattle, and as beef production is expensive the profit from game cropping was at least six times that for beef production on similar land. The problems of disease and adequate control of cropping have not been completely solved, but the approach is a promising one. This was a pilot study in one small area (50 sq. miles) only 130 miles from a very good market for the product. Before the results can be applied to other parts of Africa much more work is needed to test it fully, as the author himself points out. There is much talk these days of game cropping as a form of land use, but the practical problems of vast areas, large scale animal movements, and great distance from markets may prove incompatible with 
economic exploitation. The author briefly discusses the land-use spectrum (from the extremes of intensive farming to national parks) as applied to the African scene. He ends with a plea for public education, which is perhaps the most important single aspect of conservation in Africa, and without which the various solutions that have been proposed are bound to fail. The book is recommended as a readable and stimulating introduction to this field.

R. M. LAWS

Elephant Gold. By P. D. Stracey. Weidenfeld and Nicolson, 30s.

I enjoyed this book, partly because its author, like myself, acquired his taste for elephants against a background of undeveloped parts of Assam. Here the jungle soon got into his blood, as earlier it had into mine, and made him feel that days spent on game-paths through wild country, and nights in grass huts with the smell of wood smoke were the only life for him. It is dedicated to the memory of A. J. W. Milroy, an apt tribute, for the text deals much with his constant zeal aimed at cleaner captives and more humane handling. Few of the great catchers, from Sanderson onwards, who have devised or improved the various methods of capture, can claim an influence on the work equal to Milroy's.

The author has amassed many miscellaneous facts about elephants and the book is partly a sort of treatise on catching throughout the world-even touching on the Belgians' work in the Congo, and partly his own first-hand khedda experiences in Assam : there is little doubt which most readers will find the more attractive- and the more useful. It is, nevertheless, most readable, not too technical and well illustrated with photographs from Assam and Mysore, the areas he knew best.

E. O. SHEBBEARE

\section{On Safari, The Story of My Life. By Armand Denis. Collins, 25s.}

Well-known traveller, film photographer and broadcaster, the author is a self-avowed vagrant who has always been more interested in travel than study. Having sampled seriously various "white collar" vocations with little enthusiasm-at one time having even been a prospective monk-he decided that overseas adventure was the only life for him. Concentrating his energies on the photography of all manner of interesting peoples-amongst them the pygmies of Africa-and wild animals, he makes no secret of his high ambitions, and undoubtedly his unbounded self-confidence ensured success. Soon aware of the disturbing effects of "progress," he realised from the outset that the cultural richness of some of his subjects was already doomed, and having now witnessed thirty years' disastrous destruction of wild life he makes the (not idle) prophesy that in another thirty years much of what he has described will be a thing of the past.

Armand's wanderings have taken him to a diversity of countries. Besides filming, his activities have extended to chimpanzee farming and large-scale gorilla catching - not a pleasing undertaking, more especially as all thirty of the juveniles captured died of a mysterious disease before they could be shipped from Africa. There are too, thrilling tales of encounters with crocodiles and other dangerous animals, of the catching by hand of lusty young African elephants, of lassoing the black rhinoceros, and of the capture of that elusive, equatorial forest species, the okapi. There are excellent blackand-white illustrations, one of which prompts the thought "How stupid can a lion look ?" The answer will be found facing page 144. 